\title{
The Proctor-Parkes incident: Politics, protestants and popular astronomy in Australia in $\mathbf{1 8 8 0}$
}

Shortly after $7 \mathrm{pm}$ on Sunday $5^{\text {th }}$ September 1880 a large crowd milled about in Castlereagh Street, Sydney. They had come to hear the famous astronomer Richard Anthony Proctor speak about the relationship between science and religion. However the lecture would not be given. Colonial Secretary Henry Parkes had intervened, using his powers to threaten the owner of the theatre and prevent this Sunday entertainment from proceeding. This was a remarkable win by the resurgent Sabbatarian movement in New South Wales, and a long-remembered controversy in Australian public life ${ }^{1}$.

In 1880 Proctor was one of the most famous scientific popularizers in the Englishspeaking world ${ }^{2}$. From May to December of that year he undertook a triumphant tour of Australia and New Zealand. Skillfully managed by the impresario Robert Sparrow

Smythe, Proctor delivered more than a hundred lectures to large audiences ${ }^{3}$ in most of the colonies, and gained attention in all of them. Controversy was very much a part of his success.

Proctor's tour, and the Proctor-Parkes incident in particular, had a high profile at the time and there were long memories of both ${ }^{4}$. Despite this, they have been little studied. There is only one academic publication that directly addresses the dispute ${ }^{5}$ while Proctor's tour does not appear in any of the major works on the history of Australian 
astronomy. Proctor's appearance in these histories is limited to his role in the controversy about Eta Argus ${ }^{6}$, an event that will be discussed below.

The historical lacuna concerning Richard Proctor in Australia is notable. In recent decades scholarship has started to fill the gap between popular processes as an important part of the history of science and the cultural value of popular scientific discourse, from both directions. Richard Proctor is a well-studied figure in this regard. However his Australian activities have received almost no attention. In general, the history of popular science in Australia remains understudied, with some notable exceptions ${ }^{7}$. This essay provides an overdue study of the Proctor - Parkes incident and its historical context.

Examination of this incident reveals two aspects of the action of science communication within culture. The first of these is about the nature of popular science. Scholars such as Hilgartner and Bucchi have described a continuum of popularization from intraspecialist to popular levels of communication ${ }^{8}$. Consequently there is a range of motivations for such popularization, including persuasion, pedagogy and inspiration. Achieving success at multiple levels, as Proctor undoubtedly did, involves the use of content that is pertinent within the narrow contexts of specialisation, but which is also able to create cultural meaning for that content in broader contexts by mobilising and transforming its analogical connections.

The second aspect is in regard to popularization as an "umbrella category" ${ }^{\text {. }}$ Popular astronomy as practised by Proctor engaged a tradition that extended far back in time. Many of the analogical connections through which he infused his popularization with meaning comprised a distinctive set of concerns that had been associated with 
astronomy for centuries. I use the term cultural schemata to describe these clusterings of long-standing associations, capable of being recalled and thus able to influence interpretation and meaning-making ${ }^{10}$. Different traditions of popularization, especially those associated with different forms of science, invoked very different cultural schemata, which in turn had consequences for the contexts in which, and the audiences for whom, they were practised. Much as we now understand science as a heterogeneous assemblage of practices, so too we should better appreciate 'popular science' in an analogous fashion.

The cultural schemata of popular astronomy were shared widely-indeed, there was a global network of trade underlying these popularizations-but these schemata also developed in particular ways in Australia. Astronomy was, indeed, a foundational science for colonialism, enabling the practices of navigation, surveying and public time. The use of objects of the southern sky as symbols of nationhood has been a persistent feature of Australian self-perception. The Southern Cross is well-known in this respect; a lesser appreciated aspect is how strong interest in the comets seen first from the southern skies in the nineteenth century helped create an Australian identity ${ }^{11}$. The role of and trading chains for communicative technologies in the colonies were highly significant to the development of Australian culture ${ }^{12}$. These displayed both connection with and distance from remote locations. Popular astronomy helped sustain the global imaginary of Australia in all of these ways and more, and no individual in the late nineteenth century had more impact on astronomical popularization in Australia than Richard Proctor. 


\section{The development of Proctor's Australasian tour}

Proctor had a number of motivations for his tour of Australia and New Zealand. He had been struggling financially ever since the collapse of the New Zealand Banking Corporation in 1866 took what remained of Proctor's inheritance ${ }^{13}$. In the post-goldrush era Australians enjoyed the highest incomes in the world ${ }^{14}$ and thus appeared as a lucrative market. Moreover, the Australian colonies at this time were especially populated with people likely to be a receptive audience. Nineteenth century migrants to Australia were not "the poorest of the poor" ${ }^{\text {, }}$, and there had been a significant influence from Chartist ideals ${ }^{16}-$ Henry Parkes himself had once associated with Chartism ${ }^{17}$. Both of these factors helped shape a society with a relatively healthy respect for knowledge and learning. Even more proximately, the death of Proctor's wife Mary (nee Mills) in 1879 led Proctor to seek distraction in work. A meeting in London between Proctor, Smythe and Frederick William,Haddon, editor of the Argus ("the voice of Victorian conservatism"18) sent the astronomer on a voyage intended to be both diverting and lucrative.

Despite the favourable conditions, the eventual popularity of Proctor's tour was by no means certain. Platform lecturing did not have a strong tradition in Australia at that time. Smythe himself had managed few speakers previously in Australia, most successfully the Reverend Charles Clark ${ }^{19}$. Smythe refused to guarantee even Proctor's passage out, so unsure was he of the prospects. Yet Proctor earned around $£ 5000$, more than he had on his first tour of the USA and many times a government or university astronomer's salary ${ }^{20}$. The Thames Advertiser reported a claim that Proctor cleared as much in Dunedin alone as he had in New York ${ }^{21}$. 
Proctor's success was grounded in the cultural context of the times and in the skill of his manager but also in his performance. He presented as a modern lecturer, deploying authority as a global expert, rather than as a "scientific and ingenious townsman"22 of an earlier age. In his use of visual technology, too he was up-to-date. In less skilful hands, the magic lantern could appear as "horrible vague images, often upside-down"23 but Proctor's use was exemplary, including the latest photographs from the Melbourne Observatory and spectacular images such as those from James Nasmyth's ground-) breaking work The Moon Considered as a Planet, a World and a Satellite ${ }^{24}$. Above all, his lectures engaged contemporary issues in science, philosophy and religion.

Proctor in Australia had a repertoire of seven lectures. The first, and most commonly delivered, was "Life and Death of a World", in which he outlined his framework of cosmic evolution with respect to the Earth and other planets. Most of his other lectures focused on particular solar system or stellar objects. "Other Worlds than Ours" gave his views on the subject with which he first had success-the possibility of life on other planets, known at the time as the 'plurality of worlds' debate. Proctor's final lecture, "The Birth and Growth of the Universe" described his view of the relations between science and religion, discussed nebular theory and reprised his framework of cosmic evolution. Proctor modified this last one into "The Vastness of God's Universe" in Australia after the Parkes incident. Despite claiming that his success in New Zealand was largely due to the Parkes controversy, he did not deliver his seventh lecture there. Only Melbourne and Sydney audiences heard and saw all seven. Table 1 and Figure 1 summarise Proctor's lecturing schedule in Australia and New Zealand as gleaned from contemporary newspaper reports and advertisements.

\section{TABLE 1 OVERVIEW}


FIGURE 1 MAP

\section{Proctor's reputation built through controversy}

It is not surprising that the role of controversy was paramount to the success of Proctor's Australasian tour; even Australian critics of Proctor's sensationalism acknowledged its value ${ }^{25}$. Indeed, he had largely been brought to the attention of the Australian public through public disputes in the 1870s. The most significant of these will be described here.

\section{Proctor's early disputes about the organization of science}

Proctor's first brush with controversy came with his 1870 book Other Worlds Than Ours. This work, on the plurality of worlds, was Proctor's breakthrough success, but it also brought into public view Proctor's dispute with Norman Lockyer over the nature of the Sun's corona ${ }^{26}$. (Lockyer considered the phenomenon to be partly caused by refraction in the Earth's atmosphere; Proctor believed it to be purely solar in origin.)

The antagonism between the two developed over the question of the organisation of research expeditions to observe solar eclipses and the transit of Venus. Proctor grew increasingly frustrated with the management of these expeditions by Astronomer Royal George Airy, a close confidant of Lockyer's. Proctor thought that Airy's arrangements would not provide answers to the scientific questions at stake, such as the tests 
suggested by Proctor to help resolve the question of the corona. When Proctor, as secretary of the British Astronomical Society, published a critique of Airy it was too much: Proctor was forced to resign ${ }^{27}$. Proctor had come to feel that government support for scientific research, while admirable in principle, inevitably led to corruption in practice; he believed that scientists should be more entrepreneurial and be able to live off their public writing as he, and a few other scientists like Huxley could do ${ }^{28}$.

Proctor's writing was certainly prolific. He reworked his writing many times, publishing similar columns in multiple newspapers, and then republishing them in his books, but he also wrote prolifically, reportedly for a hours every night. His manager in the USA, Charles Carter was reported as saying that

during the tour Proctor would often seclude himself for an hour and a half before dinner and come down from hís room fresh and smiling with_-"Well, Carter, I've earned fifty dollars-here's another article." ${ }^{29}$

Much of his output was reprinted in Australian newspapers. He was a particular favourite of the Australasian, the weekly version of the Argus. One subject that these papers-and many others-reported on was Proctor's speculations about comets.

\section{Courting interest in the apocalyptic potential of comets}

In 1876, a 'new star' was detected in the constellation of Cygnus. It flared up suddenly and then faded over the course of the next few weeks. This observation was interesting enough-variable stars and novae were a puzzle for astronomy at the time. The 
attention given to the discovery in the Australian papers was, however, completely eclipsed by Proctor's commentary on it.

Proctor's commentary, "Suns in Flames", originally appeared in March 1877 in the London magazine Belgravia and was précised in the Australian papers within months. In his article, Proctor wrote that a cometary impact with the sun could destroy all life on Earth. Given both the spectacular nature of this claim, and the widespread Australian interest in comets in the nineteenth century, it is no surprise that his article was noticed.

Proctor' commentary began with an assessment of the effects on Earth should the Sun experience a similar burst of activity: "the creatures on the side of the earth turned towards him at the time would be destroyed in an instant." Nor would those on the night side be spared. "In much briefer space the effect of his new fires would be felt all over the earth's surface. The heavens would be dissolved and the elements would melt with fervent heat."

Proctor speculated about a possible cause for such outburst-meteoritic impacts associated with the passage of a large comet. Although he would conclude that such a catastrophe was "exceedingly unlikely" the rhetorical impact had been made: Proctor says that a meteor colliding with the Sun could extinguish life on Earth. This message was indeed inferred by many, such as the Scientific American which picked up Proctor's theory and included it in a list of ten possible 'fates' for the "last man" on Earth ${ }^{31}$.

Like the Belgravia commentary, the Scientific American article was reported in Australia $^{32}$. A telling indicator of the impact of this theory was its use in jocular asides, 
such as when the Queenslander reported during a brief heatwave that "everybody was disposed to believe that Mr Proctor's theory anent a momentary increase of solar heat, by that much-abused comet, might be coming true." ${ }^{33}$

\section{Proctor's prior Australian controversies}

Proctor's apocalyptic speculations were noted across the world, but he was particularly noticed in Australia for the local disputes in which he was involved. One of these was the dispute between the Tasmanian amateur astronomer Francis Abbott and British astronomers John Herschel and George Airy over the appearance of the nebula Eta Argus (now known as Eta Carinae). The physical nature of nebulae was one of the biggest questions in nineteenth century astronomy, and Eta Argus was one of the most interesting. It was also inaccessible to northern telescopes making its study of particular significance to southern hemisphere astronomy.

Abbott came to believe that the nebula had changed considerably in appearance since it had been drawn by John Herschel at the Cape of Good Hope in 1838. Things came to a head in 1868 when Abbott produced not just a report but a drawing of his observations $^{34}$. This was scrutinised by Herschel himself who published a condescending report that suggested Abbott had misinterpreted his observations ${ }^{35}$. Richard Proctor picked up on this dispute and published an article in Fraser's Magazine, taking Herschel's side ${ }^{36}$. Abbott appealed directly to Proctor for an opinion in 1871 but Proctor backed the judgement of Herschel even more strongly: Abbott was an incompetent observer ${ }^{37}$. When Airy provided a third opinion that was scathing of the quality of Abbott's drawings Abbott's reputation in Europe was shredded. This incident 
was a clear assertion of the authority of professional astronomers over amateurs, and despite his growing unease with the value of government-funding, he nonetheless leant his growing popular status to side fully with professional astronomers against amateurs.

Proctor was drawn into another local controversy in $1870-$ for once unwittingly. The amateur astronomer (and popular science lecturer) Henry Severn waged a campaign against the design of the Great Melbourne Telescope and its astronomer Albert Le Sueur, initially through letters to The Argus and culminating in a scathing paper read at a meeting of the Royal Society of Victoria ${ }^{38}$. One of the pieces of evidence Severn tendered was Proctor's opinion of the merits of reflector telescopes like the Great Melbourne Telescope. Proctor's name would be invoked more than once as Severn, and Le Sueur and Robert Ellery on behalf of the Observatory, traded barbs through the press. Although not directly involved, this incident helped keep Proctor's name in the minds of the Australian public, and associated with controversy.

A more minor dispute occurred on the eve of the tour itself. It was reported that New South Wales Government Astronomer Henry Chamberlain Russell Russell had agreed with an assistant's claim to have observed the shadow of a comet on the Moon. Proctor said that such a notion was ridiculous; the observation was a natural shading on the surface. A number of Australians in London took offence on Russell's behalf and claimed that he had been misunderstood. Russell himself wrote to The Observatory to complain about Proctor's article but by the time he arrived in New South Wales no ill feeling was evident between Proctor and Russell ${ }^{39}$. 


\section{Proctor sustains his celebrity on tour through controversy}

Proctor's tour of Australia and New Zealand itself started with a small public controversy. Finding it unexpectedly difficult engage a lanternist cheaply in Melbourne, Proctor borrowed a lantern from Robert Ellery of the Melbourne Observatory at short notice just before his second lecture. In the rush to set it up the two gas tubes-oxygen and hydrogen-were accidently swapped ${ }^{40}$. As a result on the second night the images were dim and on the third the hydrogen ran out: several illustrations had to be omitted. This was more than a mere inconvenience. Visual communication was central to Proctor's popularization. One omitted illustration was a chart of the surface of Mars, a particular area of Proctor's scientific expertise, important both to his personal claims for authority and to advance his thesis of cosmic evolution ${ }^{41}$.

Proctor attempted to deflect attention from the failure of the lantern equipment but in doing so complained about the competence of Melbourne lanternists ${ }^{42}$. One local optician took offence at this slur and a brief exchange of letters appeared in the $\operatorname{Argus}^{43}$. Proctor and Smythe quickly called on Wood and the matter was smoothed over. Although trivial in itself, this dispute revealed a pattern that would be seen more than once over the course of the tour: Proctor sensitive to slights on his professionalism and quick to respond condescendingly but equally quick to diplomacy in an effort to resolve matters. The pattern would repeat but later disputes would not prove as tractable.

Proctor would also soon build on his notoriety in regards to speculations about comets. He penned an article for the Victorian Review that referred to the comet observed in Australia earlier that year, and incorporated the new material into his lecture on comets 
and meteors ${ }^{44}$. Although scepticism about these theories was registered in letters to the editor, the widespread impact of them was clear ${ }^{45}$.

\section{Proctor's views about science and religion}

However, the most controversial aspects of Proctor's lectures in Australia were about the relationship between science and religion. Proctor was an advocate for the autonomy of professional science: from amateur involvement, from state support, and from religious interference.

Proctor's own religious opinions were complex. Initially an orthodox Anglican, Proctor had indeed commenced his university studies in theology, intending to enter ministry. He converted to Catholicism upon marrying Mary Mills, but publicly renounced this after her death. Proctor became increasingly anti-clerical and sympathetic to freethought, yet declared himself an agnostic ${ }^{46}$. While he clearly disagreed with the idea of a personal god, Proctor would pen a series on "The Religion of Science" for his journal Knowledge in which he would "show how to the student of the universe thoughts essentially religious present themselves. ${ }^{47}$ Lightman draws attention to the influence of Spencer on these views ${ }^{48}$. Many of these positions had been reported in Australia before his tour ${ }^{49}$.

Despite this foreknowledge, Australia's religious communities were not initially hostile to Proctor's tour but rather "clergy of all denominations from the Bishop of Melbourne downwards, recommended their congregations to go and hear the eminent lecturer." The Reverend James Jefferis, Congregationalist minister in Sydney and Proctor's later 
disputant, first mentioned Proctor in a sermon delivered in Adelaide at the opening of the Congregationalist Church at College Park ${ }^{51}$. Jefferis had heard Proctor speak about "The Moon-Our Companion Planet" at the Melbourne Athenaeum on the $8^{\text {th }}$ June and his tone was generally positive.

However, religious disquiet with Proctor's lectures grew throughout the tour. To understand the basis for this, I will examine in more detail the content of Proctor's lectures.

\section{Religious implications of the themes in Proctor's popular astronomy}

\section{The theme of the history of astronomy}

Proctor would start his primary lecture, "Life and Death of a World", with an invocation of the history of astronomy:

From time to time we learn that the great astronomers Copernicus, Galileo and Newton first discovered and established the true law of the solar system, and it was only after that discovery that men began to recognise the vastness and immensity of the scale on which the universe is built. ${ }^{52}$ 
In fact, the start of every one of Proctor's lectures included a reference to historical astronomy, whether to earlier superstitions in "Comets and Meteors" or a description of the Mesopotamian origin of constellations in "The Star Depths".

This focus on history was not unique to Proctor; more than is the case in most popular sciences, astronomy deploys its own history. One of the most frequently invoked implications was of astronomy as an exemplary science, the one that had discovered "the true law of the solar system". By the nineteenth century astronomy was regarded as a mature branch of science, and it would be the first science treated in many compendia. For many, a history of astronomy stood for a history of science, or indeed thought itself $f^{53}$. This cultural position was clearly significant with regards to religious controversies; it is no coincidence that both theology and astronomy were described as "The Queen of the Sciences"

\section{The theme of the astronomical sublime}

Another way that Proctor's popularization intersected with religious sensibility was his appeal to the sublime in describing the "the vastness and immensity of the scale on which the universe is built". Again, this association was not unique to Proctor. The connection between the sense of the sublime and astronomy had already been much noted by Proctor's time. According to Joseph Priestley, astronomy was one of "the noblest fields of the sublime that the mind of man was ever introduced to."55

The precise bases for the appeals to the sublime in astronomy are various. Some lecturers spoke of the grandeur of the mechanics coordinating the motions of the 
heavens. For others, it was an appreciation of the sheer geometrical vastness of the universe and hence smallness of Earth. Proctor emphasised the destructive powers of astronomical forces, as will be detailed in the next section. All of these had implications for the relationship between astronomy and religious thought.

\section{The theme of cosmic evolution}

One of Proctor's particular interests in appealing to the sublime was to promote the overarching framework of his lectures, the idea of cosmic evolution. According to Proctor:

The cycles of change affecting the universe must be vast, and although the gradual changes amongst the earth's solar system, and even in the other planets and the stars, are so very slow and so minute that they are almost imperceptible in a man's life time, yet it cannot but be acknowledged that changes have taken place, are now taking place, and will continue to take place. As a proof we have other globes like the earth we live in, which must have gone through the same processes, the gradual process of change that under our very eyes are taking place on this earth and have now reached a stage of life - a stage in a planet's life utterly unfit for the sustenance of animal life. ${ }^{56}$

This passage expresses Proctor's framework: the universe, and all objects within it undergo a process of change; different planets age at different rates; and the suitability of a planet for life depends on its position within its life-cycle. More metaphorically, Proctor would continue by explaining that worlds run their course "through burning 
childhood, fiery youth, manhood, old age and decrepitude, to the final stage-that of death" 57

Proctor would explicitly posit the Moon, "a planet in a more advanced stage, in that of decay and decrepitude”, as a picture of the Earth's bleak future before concluding his lecture a climactic appeal to the sublime:

There are more than a hundred million stars visible through a single telescope, and each star is the centre of a solar system: supposing that life exists on one planet, in each system it must exist in a hundred millions of worlds. There must be hundreds of millions of worlds in all the stages of preparation, some emerging into life, others declining to decay and death.

Life there has been for the infinite past, there will be life for the infinite future. $^{58}$

\section{Audience responses to Proctor's themes}

The clear framework of cosmic evolution that Proctor presented undoubtedly increased the memorability of his lectures. Certainly his audiences easily perceived that theme ${ }^{59}$.

Two aspects of Proctor's theme of cosmic evolution were seen as being theologically concerning. Firstly, his future for the Earth as a cold dead world went against the orthodox Christian vision of a future paradise under the second coming of Christ, at least so far as that was interpreted literally. Secondly, the idea of a multiplicity of inhabited worlds was difficult to reconcile with the notion that Christ's redemption was 
singular, and thus there could be only one world of men ${ }^{60}$. It was for this latter reason, Golinski suggests, that the concept of the astronomical sublime was deployed in order to protect speculations about life on other planets against suspicions of theological heterodoxy ${ }^{61}$.

Correspondents to the newspapers picked up on both of these theological concerns and some felt that Proctor's lectures were "highly injurious to divine revelation and the Christian faith" ${ }^{, 62}$. Proctor occasionally replied to such correspondents, but remarking that his lectures were "not intended either for the uneducated or the feeble-minded" 63 was hardly likely to conciliate. Nor was saying that

only folly little short of idiocy can cause any decently educated person to regard the vastness of the universe, its immense duration in time, and the perfection of the laws which have fashioned its various parts, as reasons for abandoning belief in an omnipresent everexisting Being ${ }^{64}$

The theological questions came to a head in Sydney. Back in front of his own congregation, James Jefferis selected the subject of "The Highest Teachings of Astronomy" as the subject for his sermon on Sunday $29^{\text {th }}$ August. This was brought to Proctor's attention, and he introduced his lecture on Saturday $28^{\text {th }}$ August with a brief discussion of the relationship between science and religion as he saw it. Proctor reprised his views: that science and true religion must be compatible; that God's nature and thoughts were unknowable; and that the incomprehensible vastness of time and space revealed by astronomy stood as a lesson for this. But although Proctor stressed the general consistency of science and theology, he nonetheless addressed some pointed comments towards religions in particular. Proctor 
thought scientific teachings were chiefly valuable ... because they indicated the universal prevalence of law, and consequently the futility of lawlessness, no matter under what high or even sacred names disguised. ${ }^{65}$

Proctor also used this occasion to announce that he would deliver his final lecture, on "The Birth and Growth of the Universe", on a Sunday, $5^{\text {th }}$ September.

Jefferis delivered his sermon, and for good measure followed this up with a letter to the Sydney Morning Herald the following week. This time there was no holding back. According to Jefferis, Proctor was "not very careful in his dealings with theology." 66 Proctor replied archly with a letter that not only showed that he was familiar with the texts in question but which pointed out his own theological training ${ }^{67}$. A second, more conciliatory letter from Jefferis appeared, apologizing for relying on the reports in the press-he had not actually been present at Proctor's lecture-and attempting to reconcile the differences between the astronomer and himself.

\section{Proctor's Sunday lecture is cancelled}

The theological argument stood there, but that was only the prelude to the full drama in Sydney. Proctor's announcement of a Sunday lecture-at the theatre where freethinkers were accustomed to lecturing on that day-offended Christians of a Sabbatarian inclination, those who wished to restrict commercial activity on Sundays, many of whom would go on to re-form the Lord's Day Observance Society in the wake of Proctor's tour. They lobbied the Premier of New South Wales, Sir Henry Parkes, 
including in person by protestant clergy such as Presbyterian minister John McGibbon and through the press in letters to the editor ${ }^{68}$.

Parkes decided to act. On Thursday $2^{\text {nd }}$ September Parkes instructed Inspector-General of police Edmund Fosbery to prevent the lecture from taking place in the terms advertised. Fosbery called on Smythe and told him that the lecture was illegal and not to be delivered. Smythe immediately wrote to Parkes detailing reasons to believe that the lecture was legal. Amongst other things he pointed out that no money would be taken at the door for Proctor's lecture, and that exactly the same arrangement had prevailed in London for many years without complaint. This was, in fact, not entirely true. Sunday lecturing was still somewhat controversial in London in 1880; there had been successful prosecutions against them little more than a decade earlier, and the law that was relied upon for these prosecutions was not repealed until $1896^{69}$. Proctor was promoting in New South Wales a campaign he had supported in England, rather than transferring a well-established practice.

In any case, Parkes stood firm. On the Friday he reiterated his stance and again Smythe replied: in deference to Parkes' decision no further Sunday lectures would be given but it was impossible to return the tickets already sold and since they were convinced it was lawful the lecture would be given. On the Saturday evening the Inspector-General of Police, Fosbery, visited the owner of the theatre, Samuel Lazar and informed him that Parkes would revoke his theatrical licence if the lecture were given. Lazar had a long meeting with Proctor and Smythe on the Sunday and they confirmed their intention to proceed. Fosbery returned once more, repeated his threat and a little more than two hours before the start of the lecture Lazar wrote a pleading note to Proctor asking him to call off ${ }^{70}$. 
Details of what happened next are readily available from the newspaper reports ${ }^{71}$.

Crowds started milling from 7 o'clock and soon a crowd of more than 2000 assembled in front of the Theatre Royal. Specially laid on ferries and trains had brought some of them from across the harbour and others in from the suburbs; the commercial arm of the government at least was supporting the lecture. Around 7:45pm, when word had spread that the lecture was not going to be given, Proctor appeared on the balcony of the Oxford Hotel next door and addressed the crowd:

I shall ask you, as soon as you possibly can, to disperse. In this matter I have acted, not from any consideration of my own interests, but because I was assured by the lessee of the Theatre Royal that his license would have been revoked by the Colonial Secretary-(groans) — who has the power to do so. (Cries of "Shame.") I need hardly tell you that, so far as my own risk was concerned, I was prepared to have run that risk. (Cheers.) I am a law-abiding citizen, and I obeyed the law. With the loss of the Theatre Royal it was a question of ruin; with me it was a question of a few hundred pounds. In this matter I have only yielded at the last moment to what is, practically, police interference. (A Voice: "Try again next Sunday.") I appeal to you, as good and loyal citizens, to retire to your several homes as quickly as possible. One thing we may do before we retire, and that is to give three cheers for law and order, and three cheers for the Queen. ${ }^{72}$

A major public controversy erupted. Sabbatarians were delighted. Liberal-minded Australians, including much (although not all) of the press, condemned the actions as those of a bully ${ }^{73}$. Prominent Protestant clergy lined up to congratulate Parkes ${ }^{74}$, although they were quick to point out that they had no argument with the facts of astronomy $^{75}$. A Unitarian minister McDonnell offered his church for Proctor to speak at on Sunday in the wake of the incident ${ }^{76}$ and undoubtedly there were other liberal 
ministers who wholeheartedly supported Proctor's vision of compatibility between science and religion, but none of that was expressed in public. The Catholic Freeman's fournal-never very fond of the Sabbatarian movement but very fond of haranguing Parkes-was critical of the decision, although it would seem to have been more through a desire to attack the Colonial Secretary than to defend Proctor ${ }^{77}$. According to the fewish Herald "Judaism alone stood quietly by, and said nothing, because it had no cause to fear any danger from the revelations of science ${ }^{78}$. (Proctor did manage to offend Australian Jews by the end of the year. An article written while in New Zealand suggested astronomical connections between Jewish rituals and sun-worship. The fewish Herald suggested that his opinions in this matter should be taken "cum grano salis" ${ }^{79}$.)

The Sabbatarian movement was then on the rise in the Australian colonies but they had not always had success. The government of New South Wales had never itself made concessions to Sabbatarianism. Not only would the trains and ferries always run on Sundays, but the government insisted that licensed ticket sellers remain open on the Lord's Day, not just its own employees ${ }^{80}$. In other colonies Sabbatarians had been more successful-museums and railways had been closed on Sundays at various times in South Australia and Victoria ${ }^{81}$.

It was in Victoria that Sabbatarians had had a prior success that had inspired them. That too involved police interfering with a famous British popularizer's Sunday lecture on astronomy. This was John Henry-the 'Professor'-Pepper. 


\section{Professor Pepper's Sunday lectures}

Professor Pepper was, like Proctor, a prominent British popularizer down on his luck and trying a tour of the colonies. Although it started well, Pepper's tour of Australia from 1879-1880 was much less successful than Proctor's would be a year later. Initially lecturing to full houses, by the end of a six week run at the St George's Hall in Melbourne, audience numbers had started to drop away. Pepper's audience numbers dwindled in the more competitive entertainment environment of Sydney, leading to changes in his routine, including a greater emphasis on the 'Ghost' routine, made famous at the London Polytechnic.

Pepper started a second season in Melbourne after touring through country New South Wales, Tasmania and country Victoria. This second season was not nearly as successful as his first. By June 1880, after Proctor had swept through Melbourne, Pepper was offering his services to the education department. In August Pepper took his operation to Adelaide, just weeks after Proctor had appeared. He met initial success but the operation collapsed under financial and personal strains, which included Pepper being taken to court for non-fulfilment of contract ${ }^{82}$. In the aftermath of this incident Pepper sold his equipment and moved to Brisbane where he took a position as Government analyst, retaining his sideline of schools lecturing ${ }^{83}$.

One of the more significant changes to Pepper's repertoire to emerge in Sydney was the inclusion of astronomy into his programme. Around this time he started using, a set of commercially produced astronomy slides. In addition to working astronomical content into his general 'science festivals', Pepper also delivered lectures with a purely astronomical theme. Notably on two Sundays $30^{\text {th }}$ November and $7^{\text {th }}$ December 1879 , 
Pepper presented two 'secular sermons' at the Victoria Theatre ${ }^{84}$. Moreover, these were presented on exactly the same commercial basis that would prove so objectionable to Sabbatarians just nine months later: tickets pre-sold, with advertised prices. There was no campaign against-or even much notice of-Pepper's Sunday lecturing in Sydney. Pepper had had no background of conflict with religious authorities and his theology was more orthodox. Nor did he appear at a venue known as being a home of freethought.

Melbourne Sabbatarians were more vigilant; when Pepper started giving Sunday lectures on astronomy on his return they were noticed ${ }^{85}$. On Sunday $23^{\text {rd }}$ May 1880, in preparation for his sixth Sunday lecture, the police paid Pepper a visit: he was acting illegally by taking money at the door on Sundays and would be prosecuted if he did so. The arrangements were quickly changed; tickets were not sold and instead a collection was taken ${ }^{86}$. Pepper did give more Sunday lectures on this basis, but soon abandoned the practice. Sabbatarian lobbyists in Sydney referred to this success later that year, although they never mentioned their own inattention some nine months earlier. They were not the only ones paying less attention; in contrast with the Proctor-Parkes incident, the press payed little attention to the interference with Pepper's lecturing.

The Proctor-Parkes dispute not only received more attention at the time, it would also be remembered in Australia for a long time. This memory was particularly strong within both religious and freethought communities. In 1884 a Sabbatarian deputy to then Premier Alexander Stuart would urge him to emulate Parkes and close all theatres to secular lecturers on Sundays ${ }^{87}$. In 1887, after Parkes had returned to the Premiership and done just that, it was liberals, freethinkers and trades-unionists who formed a delegation to the Premier asking him to reverse his decision. Again, the Proctor case 
was a cultural touchstone ${ }^{88}$. By 1890, after Proctor's death, freethought lecturers like William Whitehouse Collins would explicitly claim Proctor as one "of their advocates" ${ }^{89}$. The Protestant Standard disputed this description, although the year before they had been happy, at least, to claim him as an anti-Catholic ${ }^{90}$. Richard Proctor himself would be "still remembered in Australia as a fascinating lecturer" ${ }^{91}$ in 1922.

\section{Comparing the reaction to Proctor and Pepper}

A comparison between the reaction to Pepper and the later Proctor-Parkes dispute raises a number of issues. Most straightforward is the question of why was Proctor's lecture a much bigger target for Sabbatarians than Pepper's? Another question is why was astronomy considered a suitable subject for Sunday lectures in the first place? The answer to both of these questions address the claims made at the start of this essay. These two claims, in the terms that Ihave used above, are firstly that engagement with cultural schemata is characteristic of successful popularization, and secondly that the cultural schemata of popular astronomy are distinctive with respect to the traditions associated with the popularization of other sciences.

Proctor's Australian lectures deliberately engaged issues and ideas like Sunday lecturing, evolution and cometary destruction. These cultural tropes were drawn from multiple timescales; freethought was a recent campaign, while the astronomical sublime was a long-standing cultural schema. Proctor was able to be simultaneously modern, yet engaging with the weight of tradition. The clear framework in which he presented his material meant that audiences could readily negotiate complex material in a simple fashion. Pepper, on the other hand, presented more as an old-fashioned entertainer. His 
“science festival" style had once been successful, but by 1880 was losing its appeal ${ }^{92}$. His impact was reduced and he had trouble drawing repeat audiences.

\section{The cultural schemata of astronomy}

However, there were also clear similarities between Proctor and Pepper as well. Pepper was less adept at deploying the cultural schemata, but his astronomical lectures invoked many of the same themes as Proctor-just as earlier astronomy popularizers had done, and subsequent ones would continue to do. These schemata have been outlined above: the sense of the astronomical sublime, astronomy as an exemplary science, and the persistent association with the science of the night sky and religious thought.

This set of cultural schemata is clearly unique to astronomy, although individual aspects of them can be seen in other traditions. For example mathematics was also called "Queen of Sciences" ${ }^{93}$, but mathematics does not generate the same sense of the sublime. Almost by definition, only astronomy studies the universe at such a large spatial scale.

These schemata were long-standing; Proctor was certainly not the first to deploy the connections between astronomy and religion. The 'plurality of words' debate had recognized theological significance for centuries. Astronomy was also invoked regularly in nineteenth century debates over Darwinism, as much due to its cultural status than in terms of precise facts, which were much more rarely cited. Proctor mobilised a welldeveloped tradition, and his treatment was able to focus the attention of both friends and opponents upon his views about religion. 
The considerable success of Richard Proctor was due to his ability to authoritatively speak to the details of astronomical science while linking them with broader cultural meanings that were understood by and important to his audiences. The cultural schemata of astronomy operated by enmeshing the knowledge practices of specialist researchers with the lived experiences of non-specialist publics.

These meanings combined in many ways and skies above Australia held different powerful meanings for diverse groups of people. The stars over Castlereagh Street in September 1880 were infused with various ideals-freedom, progress, duty-in a way that would not be lightly forgotten. 


\section{References}

1 'Australiana: Topical, Reminiscent, Historical', World's News (Sydney, NSW, 15 November 1919), p. 3.

2 B. Lightman, Victorian Popularizers of Science: Designing Nature for New Audiences (University of Chicago Press, 2009), p. 299 <https://books.google.com.au/books?id=ady3NSvPi_8C>.

3 '(no Title)', Otago Daily Times (Dunedin, 7 December 1880), p. 2.

4 'Proctor's Paradoxes', Recorder (Port Pirie, SA, 7 June 1922), p. 4; 'A Starette', Truth (Sydney, NSW, 14 April 1912), p. 4.

${ }^{5}$ Walter Phillips, 'The Churches and the Sunday Question in Sydney in the 1880s', Journal of Religious History, 6.1 (1970), 41-61.

${ }^{6}$ Raymond Haynes, Explorers of the Southern Sky: A History of Australian Astronomy (Cambridge ; New York: Cambridge University Press, 1996), p. 137; Wayne Orchiston, 'The Contribution of Francis Abbott to Tasmanian and Australian Astronomy', Vistas in Astronomy, 35, Part 3.0 (1992), 315-44 <https://doi.org/10.1016/0083-6656(92)90011-T>.

7 Wayne Orchiston, 'The Role of the Amateur in Popularizing Astronomy: An Australian Case Study.', Australian Journal of Astronomy, 7 (1997), 33-66; Lindy A. Orthia, "Laudably Communicating to the World": Science in Sydney's Public Culture, 1788-1821', Historical Records of Australian Science, 27.1 (2016), 1-12.

8 Stephen Hilgartner, 'The Dominant View of Popularization: Conceptual Problems, Political Uses', Social Studies of Science, 20.3 (1990), 519-39 <https://doi.org/101177/030631290020003006>; Massimiano Bucchi, 'Of Deficits, Deviations and Dialogues: Theories of Public Communication of Science', in Handbook of Public Communication of Science and Technology, ed. by Massimiano Bucchi and Brian Trench (London: Routledge, 2008), pp. 5776.

${ }^{9}$ Ralph O'Connor, 'Reflections on Popular Science in Britain: Genres, Categories, and Historians', Isis, 100.2 (2009), 333-45.

10 Peter Burke, 'Strengths and Weaknesses of the History of Mentalities', History of European Ideas, 7.5 (1986), 439-51.

11 'The Australian Comet', South Australian Register (Adelaide, SA, 12 April 1843), p. 3.

12 Geoffrey Blainey, Black Kettle and Full Moon (Penguin Group Australia, 2004), p. 88 <http://books.google.com.au/books?id=8MlZo9tiIKYC>; Elizabeth Hartrick, 'Consuming Illusions : The Magic Lantern in Australia \& Aotearoa/New Zealand' (University of Melbourne, 2003), pp. 44, 239, 247. 
${ }^{13}$ Lewis O Saum, 'The Proctor Interlude in St. Joseph and in America: Astronomy, Romance and Tragedy', American Studies International, XXXVII.1 (1999), 3454.

${ }^{14}$ I.W. McLean, Why Australia Prospered: The Shifting Sources of Economic Growth, The Princeton Economic History of the Western World (Princeton University Press, 2012), p. 12 <http://books.google.com.au/books?id=Veq35KMGSI8C>.

15 Eric Richards, 'How Did Poor People Emigrate from the British Isles to Australia in the Nineteenth Century?', Journal of British Studies, 32.03 (1993), 250-79 <https://doi.org/10.1086/386032>.

16 HL Harris, "The Influence of Chartism in Australia", The Royal Australasian Historical Society: Journals and Proceedings, 1926, 351-78; Hugh Collins, 'Political Ideology in Australia: The Distinctiveness of a Benthamite Society', Daedalus, 114.1 (1985), 147-69 <https://doi.org/10.2307/20024958>.

17 P.A. Pickering, M.T. Davis and D. Senior Researcher Princeton Theological Seminary USA Michael T Davis, Unrespectable Radicals?: Popular Politics in the Age of Reform (Taylor \& Francis, 2016), p. 210 <https://books.google.com.au/books?id=Av-fCwAAQBAJ>.

18 Robert Murray and Jim Usher, 'Argus', in A Companion to the Australian Media, ed. by Bridget Griffen-Foley (Australian Scholarly, 2014), pp. 24-25.

19 'A Great Entertainer', Evening Journal (Adelaide, SA, 11 September 1896), section ONE O'CLOCK EDITION, p. 2.

20 'An Editor and the "Much Travelled"' (Adelaide, 6 October 1914), p. 5.

21 '(no Title)', Thames Advertiser (Thames, New Zealand, 19 January 1881), p. 2.

22 'Muswell Brook', Maitland Mercury and Hunter River General Advertiser (Maitland, NSW, 26 June 1858), p. 2.

23 'The Lantern Slide', The Age (Melbourne, Victoria, 30 January 1937), p. 6.

24 J. Nasmyth and J. Carpenter, The Moon: Considered as a Planet, a World, and a Satellite (London: John Murray, 1874); Colleen Boyle, 'You Saw the Whole of the Moon: The Role of Imagination in the Perceptual Construction of the Moon', Leonardo, 46.3 (2013), 246-52 <https://doi.org/10.1162/LEON_a_00564>.

25 J Benvie, 'A Few Thoughts on Current Speculations', The Maitland Mercury and Hunter River General Advertiser (Maitland, NSW, 11 September 1880), p. 7.

${ }^{26}$ Charles Pritchard, 'Other Worlds Than Ours', Nature, 2 (1870), 161-62; Richard Anthony Proctor, 'Other Worlds Than Ours', Nature, 2 (1870), 190.

27 Bernard Lightman, 'Marketing Knowledge for the General Reader: Victorian Popularizers of Science', Endeavour, 24.3 (2000), 100-106 (p. 303) <https://doi.org/10.1016/S0160-9327(00)01307-7>.

${ }^{28}$ Richard Anthony Proctor, Wages and Wants of Science Work, Social History of Science (Taylor \& Francis, 2012), pp. 34-35, 41-43 <https://books.google.com.au/books?id=Yj0sBgAAQBAJ>. 
29 'Richard Anthony Proctor', South Australian Advertiser (Adelaide, SA, 9 July 1880), p. 6.

30 Richard Anthony Proctor, 'Suns in Flames', Belgravia, March 1877, 32-52.

31 'The Fate of the Last Man', Scientific American, 36.21 (1877), 321.

32 'Scientific. A Sun in Flames', The Australasian (Melbourne, Victoria, 17 March 1877), p. 6; 'Science.', Riverine Grazier (Hay, NSW, 4 July 1877), section Supplement to the Riverine Grazier, p. 2; 'Scientific. The Fate of the Last Man.', The Australasian (Melbourne, Victoria, 4 August 1877), p. 7.

33 'Maryborough', The Queenslander (Brisbane, Queensland, 28 February 1880), p. 263.

${ }^{34}$ Francis Abbott, 'On the Variability of Eta Argus and Surrounding Nebulae', Monthly Notices of the Royal Astronomical Society, 28.7 (1868), 200-202.

35 John F. W. Herschel, 'On the Variable Star Eta Argus and Its Surrounding Nebula', Monthly Notices of the Royal Astronomical Society, 28.8 (1868), 22529.

${ }^{36}$ Richard Anthony Proctor, 'The Great Nebula in Argo', Fraser's Magazine, December 1868, pp. 762-68.

37 Richard Anthony Proctor, 'Note on Mr. Abbott's Imagined Discovery of Great Changes in the Argo Nebula', Monthly Notices of the Royal Astronomical Society, 32.2 (1871), 62-64.

${ }^{38}$ Henry A. Severn, 'The Great Melbourne Telescope', The Argus (Melbourne, Victoria, 24 February 1870), p. 7; 'Royal Society of Victoria', The Argus (Melbourne, Victoria, 14 June 1870), p. 6.

${ }^{39}$ Henry Chamberlain Russell, 'A Startling Astronomical Discovery', The Observatory, 3 (1879), 178-80.

${ }^{40}$ Richard Anthony Proctor, 'Mr Proctor's Lectures', The Argus (Melbourne, Victoria, 9 June 1880), p. 6.

41 Bernard Lightman, 'The Visual Theology of Victorian Popularizers of Science: From Reverent Eye to Chemical Retina', Isis, 91.4 (2000), 651-80 <https://doi.org/10.2307/236819>.

42 Proctor, 'Mr Proctor's Lectures'.

43 W Wood, 'Mr. Proctor's Lectures', The Argus (Melbourne, Victoria, 16 June 1880), p. 7; Richard Anthony Proctor, 'Mr. Proctor's Lectures', The Argus (Melbourne, Victoria, 12 June 1880), p. 8; W Wood, 'Mr. Proctor's Lectures', The Argus (Melbourne, Victoria, 11 June 1880), p. 3.

44 'Literature. The Victorian Review', The Australasian (Melbourne, Victoria, 3 July 1880), p. 8; Richard Anthony Proctor, Comets and Meteors, R. A. Proctor's Lectures, 4 (M. A. Cleary, 1880).

45 'Mr Proctor's "Menacing Comet"', The Maitland Mercury and Hunter River General Advertiser (Maitland, NSW, January 1883).

${ }^{46}$ Richard Anthony Proctor, 'Letters Received and Short Answers', Knowledge, 4 (1883), 338. 
${ }^{47}$ Richard Anthony Proctor, 'Sun Worship', Knowledge, 9 (1886), 137-38.

48 B. Lightman, p. 316.

49 'Evolution and Religion', Australian Town and Country Journal (Sydney, NSW, 24 April 1880), p. 27.

50 'Mr Proctor, the Astronomer', Otago Daily Times (Dunedin, New Zealand, 11 October 1880), p. 3.

51 'Opening of the Congregational Church, College Park', South Australian Register (Adelaide, SA, 14 June 1880), p. 6.

52 Richard Anthony Proctor, The Life and Death of a World, R. A. Proctor's Lectures, 1 (M. A. Cleary, 1880), p. 3.

53 'News of the Day', The Sydney Morning Herald (Sydney, NSW, 11 September 1884), p. 9.

${ }^{54}$ Report of the Third Meeting of the British Association for the Advancement of Science; Held at Cambridge in 1833 (London: John Murray, 1834), p. xiii.

55 J. Priestley, A Course of Lectures on Oratory and Criticism (William Hallhead, 1781) <https://books.google.com.au/books?id=o-ivoX7LG7wC>.

56 Proctor, Life and Death of a World, p. 3.

57 Proctor, Life and Death of a World, p. 4.

58 Proctor, Life and Death of a World, p. 8.

59 'The Critic. Mr. R. A. Proctor as a Lecturer', The Australasian (Melbourne, Victoria, 5 June 1880), p. 6.

${ }^{60}$ Grant McColley, 'The Seventeenth-Century Doctrine of a Plurality of Worlds', Annals of Science, 1.4 (1936), 385-430.

61 Jan Golinski, Sublime Science in the Late Enlightenment: Adam Walker and the Eidouranion, 2010, Yale University Office of Digital Dissemination, Humanities <http://streaming.yale.edu/cmi2/opa/podcasts/humanities/golinski04071 $0 . \mathrm{mp} 3>$.

${ }^{62}$ A Distant Observer, 'Mr. Proctor's Lectures', The South Australian Advertiser (Adelaide, SA, 21 July 1880), p. 10.

63 Richard Anthony Proctor, 'Astronomy and Religion', South Australian Chronicle and Weekly Mail (Adelaide, SA, 7 August 1880), p. 4.

64 Proctor, 'Astronomy and Religion'.

65 'Mr. Proctor's Astronomical Lectures', The Sydney Morning Herald (Sydney, NSW, 30 August 1880), p. 6.

${ }^{66}$ James Jefferis, 'Astronomy and Theology', Sydney Morning Herald (Sydney, September 1880), pp. 3-3.

${ }^{67}$ Richard Anthony Proctor, 'Astronomy and Theology', Sydney Morning Herald (Sydney, September 1880), pp. 3-3.

68 'The Government and Sunday Lectures.', Evening News (Sydney, NSW, 6 September 1880), p. 2. 
${ }^{69}$ Ruth Barton, 'Sunday Lecture Societies', in Victorian Scientific Naturalism: Community, Identity, Continuity (Chicago: University of Chicago Press, 2014).

70 'Stoppage of Mr Proctor's Sunday Lecture', The Sydney Morning Herald (Sydney, NSW, 6 September 1880), p. 6.

${ }^{71}$ Unfortunately a file on the incident from the Colonial Secretary's Office, including the report by Police Commissioner Fosbery, appears to be missing from the State Archives in NSW. This missing file was noted as long ago as 1970. See Phillips (1970), 'The Churches and the Sunday Question in Sydney in the 1880s' Journal of Religious History 6(1) 41-61 fn. 64

72 'Stoppage of Mr Proctor's Sunday Lecture'.

73 'Saturday September 18, 1880', Brisbane Courier (Brisbane, Queensland, 18 September 1880), p. 4; 'Sir H. Parkes and Mr. Proctor at Sydney', Australasian Sketcher with Pen and Pencil (Melbourne, Victoria, 9 October 1880), p. 271.

74 'The Proctor-Cum-Parkes Affair.', Evening News (Sydney, NSW, 14 September 1880), p. 3; 'The Parkes-Cum-Proctor Affair', Evening News (Sydney, NSW, 18 September 1880), p. 4.

75 'Dr. McGuven and Mr Proctor', Sydney Mail and New South Wales Advertiser (Sydney, NSW, 18 September 1880), p. 563.

76 Richard Anthony Proctor, 'Letter from Richard A. Proctor to Reverend McDonnell, 11 September 1880', 1880, Mitchell Library, Ap 38.

77 'Parkes and Proctor', Freeman's Journal (Sydney, NSW, 11 September 1880), p. 13.

78 'The Synagogues', Jewish Herald (Melbourne, Victoria, 3 December 1880), p. 4.

79 'Astronomy and the Jewish Festival', Jewish Herald (Melbourne, Victoria, 17 December 1880), pp. 6-7.

80 Phillips.

81 'The Public Library', The Argus (Melbourne, Victoria, 7 July 1883), p. 11; 'Opening Northern Railways on Sundays', South Australian Register (Adelaide, SA, 2 May 1881), p. 6.

82 'News of the Week', South Australian Chronicle and Weekly Mail (Adelaide, SA, January 1881), p. 7; 'Police Court - Port Adelaide', The South Australian Advertiser (Adelaide, SA, January 1881), p. 3.

${ }^{83}$ R F Cane, 'John H. Pepper: Analyst and Rainmaker: The Genesis of Chemistry Teaching in Queensland', Journal of the Royal Historical Society of Queensland, 9.6 (1975), 116-33.

84 'Advertising. Victoria Theatre', The Sydney Morning Herald (Sydney, NSW, 6 December 1879), p. 2.

85 Figaro, 'In the Barber's Shop', The Telegraph, St Kilda, Prahran and South Yarra Guardian (Melbourne, Victoria, 17 April 1880), p. 3.

86 'Victoria', Evening News (Sydney, NSW, 27 April 1880), p. 2.

87 'New South Wales', The Argus (Melbourne, Victoria, 24 July 1884), p. 7. 
88 'The Closing of the Theatres on Sundays', The Sydney Morning Herald (Sydney, NSW, 14 June 1887), p. 4.

89 'Sydney Freethought Hall', The Sydney Morning Herald (Sydney, NSW, 27 January 1890), p. 3.

90 'Much Ado About Nothing', Protestant Standard (Sydney, NSW, 8 February 1890), p. 3; 'Galileo, Professor Proctor, and the Papacy', Protestant Standard (Sydney, NSW, 23 March 1889), p. 9.

91 'Proctor's Paradoxes'.

92 William Knibb Morris, 'Letters, William Knibb Morris to Thomas John Morris, July 1877-1880', 1880, University of Tasmania Special \& Rare Collections, Private Deposit M13/6.

93 W. Sartorius von Waltershausen, Gauss: Zum Gedächtnis, 108 p. (Leipzig: S. Hirzel, 1856), p. 79 <//catalog.hathitrust.org/Record/011640456>. 